\title{
Effect of sugar cane (Saccharum officinarum) wastes on the quality of Nworie river, Owerri, Nigeria
}

\author{
L. A. NWAOGU ${ }^{1 *}$ and C. AKOBUNDU ${ }^{2}$ \\ ${ }^{1}$ Department of Biochemistry, Federal University of Technology Owerri, Nigeria. \\ ${ }^{2}$ Department of Microbiology, Federal University of Technology Owerri, Nigeria. \\ *Corresponding author, E-mail: nwogulinus@yahoo.com
}

\begin{abstract}
Analysis of S. officinarum (sugar cane) rinds-contaminated water sample and its effect on the quality of Nworie River (West-end) Owerri, Nigeria, was investigated. The results of the physicochemical and microbiological parameters were compared to those of two other samples: the free flowing point of the same river three hundred meters before the dumping point and treated tap water which serves as control. In almost all the physicochemical parameters analyzed, the $S$. officinarum rinds-contaminated water sample gave the highest value compared to the other samples, although some of the values were within WHO/FEPA accepted water standard. The total microbial loads are $4.5 \times 10^{5} \mathrm{cfu} / \mathrm{ml}$ for $S$. officinarum rinds-contaminated sample, $2.8 \times 10^{5}$ $\mathrm{cfu} / \mathrm{ml}$ for sample upstream before the dumping point and $0.8 \times 10^{2} \mathrm{cfu} / \mathrm{ml}$ for treated tap water. The study shows that the indiscriminate discharge of sugar cane rinds by the Hausa sugar cane sellers into Nworie River at west end Owerri, could be a potential threat to the quality of the river if not properly and timely checked. () 2009 International Formulae Group. All rights reserved.
\end{abstract}

Keywords: Saccharum officinarum rinds, water contamination, physicochemical, microbiological parameters.

\section{INTRODUCTION}

Clean fresh water is essential for every human endeavour. The availability of potable water determines to a large extent the location and activities of humans on earth (Okafor, 1985). The provision of potable water has been one of the cardinal objectives of successive Governments in Nigeria over the years. Potable water is important because the health and well being of the citizens depend on its availability (Ray et al., 1992). Naturally, water is prone to contamination by agricultural and industrial wastes, which comprise pathogens that cause a myriad of serious diseases when the water is taken untreated (Chapman, 1992).

Analysis of water sample for the presence of microorganisms in relation to human health requires determining principally the pathogenic organisms, the most significant of which are faecal bacteria (Gordon, 1990). Organisms found in water are involved in food poisoning, and frequent outbreaks of water-borne infections (Cholera, Salmonellosis, Gastroenteritis. etc).

Holdgate (1979) defined pollution as the introduction by man into the environment (water, land, and air) of substances or energy liable to cause hazard to human health, harm to living resources and ecological system, damage to structures and amenities or interfere with legitimate use of the environment.

At the west-end of Nworie river, Owerri, a lot of activities are going by the Hausa sugar cane sellers who dump the sugar cane rinds into Nworie river. There is to the knowledge of the author, no research work carried out on the river on the effect of $S$. officinarum waste. It is against this 
background that preliminary investigation on the effect of $S$. officinarum waste on the river was carried out with the view to ascertaining whether the river is safe for human use at that point.

\section{MATERIALS AND METHODS Sample collection}

Water samples were collected from three different sources namely: treated tap water (control), water sample from Nworie river at west-end, Owerri where $S$. officinarum (sugar cane) rinds were dumped and threehundred meters upstream the dumping site. In each case, the samples were collected using sterilized 1.51 transparent plastic containers. All samples were transported to the laboratory for analysis within two hours of collection.

\section{Physicochemical analysis}

Parameters analyzed included temperature, $\mathrm{pH}$, turbidity, conductivity, total dissolved solids (TDS), total suspended solids (TSS), dissolved oxygen (DO), biochemical oxygen demand (BOD), chemical oxygen demand (COD). Temperature was determined using a mercury thermometer. The $\mathrm{pH}$ was measured using micro $\mathrm{pH}$ meter $(\mathrm{pH}-600$ Milwaukee) standardized with buffer solutions to about $\mathrm{pH} 7$ and 14 as described by Walter (1981). The TSS, TDS, DO, BOD and COD were determined by the methods of Greenberg (1992) while turbidity was determined using the HANNA electrical conductivity meter. Nitrate, phosphate and sulphate were determined using the method as describe by James (1995).

\section{Microbiological analysis}

Water samples from the three sources were analyzed for the presence of bacteria using standard inoculation and culturing techniques. Identification and characterization of bacterial isolates were carried out following the methods as outlined by Holt et al. (1994) and Cheesbrough (1991). Total heterotrophic bacterial counts for each sample was carried out by culturing $1 \mathrm{ml}$ of each sample in Petri dishes containing 20 millilitres of MacConkey agar and incubated at $37{ }^{\circ} \mathrm{C}$ for 24 hours. The number of developed colonies was counted as colony forming units (cfu).

\section{RESULTS AND DISCUSSION Physicochemical water quality}

Studies have shown that for normal unpolluted surface waters the cycle of life is in equilibrium state (Verma and Agarwal, 2006). In this state of equilibrium a great variety of life is present, but no one species of organism predominates. The organisms present adjust to the normal range of physicochemical and biological factors characteristic of that region, but the introduction of organic materials into the water body tends to alter the life cycle of the organism, thereby destabilizing the ecosystem (Lynch and Poole, 1979).

Table 1 shows the values of the physicochemical parameters of the water samples from the study area. The $\mathrm{pH}$ of the sample ranged from 5.4 for the $S$. officinarum rinds dumped point to 7.24 for the treated tap water. The water samples collected three hundred meters before the dumping point had intermediate $\mathrm{pH}$ of 6.8. The Institute of Public Analysis of Nigeria (IPAN), reported that $\mathrm{pH}$ of water is one of the most important water parameters. An optimal $\mathrm{pH}$ range is of immense necessity for the clarification and disinfection of potable water, while a range outside the acceptable standard could enhance rancidity and subsequent presence of taste and objectionable taste as observed in the sample where $S$. officinarum rinds were dumped (5.49) which deviated from the WHO permissible $\mathrm{pH}$ range of 6.5-8.0 (WHO, 2003; Ubong and Gobo, 2001; IPAN 2005). The high temperature value $\left(31.3{ }^{\circ} \mathrm{C}\right)$ observed in the $S$. officinarum rinds-contaminated water sample (Table 1) could be attributed to the high value of TDS and TSS in the sample that absorbed heat from the sun and transferred it to the water body leading to increase in water temperature compared to ambient water temperature of $26{ }^{\circ} \mathrm{C}$ (Ubong and Gobo, 2001). This increase in water temperature may have contributed to the increase in metabolic rate of the micro-organisms as indicated by the greater microbial load at the point.

The thermal conductivity values of the three water samples are presented in Table 1. The transfer of heat by conduction results from exchange of energy when oscillating molecules collide, with a high rate of exchange occurring during more rapid 
Table 1: Values of the physicochemical parameters.

\begin{tabular}{|c|c|c|c|c|c|c|c|c|c|c|c|c|}
\hline & \multicolumn{12}{|c|}{ Parameters } \\
\hline Sample & $\begin{array}{c}\mathbf{T}^{\circ} \\
\left({ }^{\circ} \mathrm{C}\right)\end{array}$ & $\mathbf{p H}$ & $\begin{array}{c}\mathrm{C} \text { at } \\
28^{\circ} \mathrm{C} \\
\mu \mathrm{s} / \mathrm{cm} \\
\end{array}$ & $\begin{array}{c}\text { TDS } \\
(\mathrm{mg} / \mathrm{l})\end{array}$ & $\begin{array}{c}\text { TSS } \\
(\mathrm{mg} / \mathrm{l})\end{array}$ & $\mathrm{NO}_{3-}{ }^{-}$ & $\mathrm{PO}_{4}{ }^{3-}$ & $\mathrm{SO}^{4-}$ & $\begin{array}{c}\text { T } \\
(\mathbf{N T U})\end{array}$ & $\begin{array}{c}\text { DO } \\
(\mathrm{mg} / \mathrm{l})\end{array}$ & $\begin{array}{c}\text { BOD } \\
\text { at } \\
20^{\circ} \mathrm{C} \\
\end{array}$ & $\begin{array}{c}\text { COD } \\
\text { at } \\
20^{\circ} \mathrm{C} \\
\end{array}$ \\
\hline $\begin{array}{l}\text { SoRCWS } \\
\text { (A) }\end{array}$ & 31.3 & 5.49 & 15.6 & 80 & 240 & 1.85 & 0.85 & 28.80 & 4.68 & 1.40 & 24.0 & 76.0 \\
\hline $\begin{array}{l}\text { WSUDS } \\
\text { (B) }\end{array}$ & 27.5 & 6.90 & 18.1 & 40 & 40 & 0.60 & 0.18 & 4.13 & 1.68 & 2.30 & 16.0 & 25.0 \\
\hline $\begin{array}{l}\text { TTWS } \\
\text { (control) } \\
\text { (C) }\end{array}$ & 26.0 & 7.24 & 20.4 & ND & ND & ND & ND & ND & ND & ND & ND & 1.00 \\
\hline $\begin{array}{l}\text { WHO/ } \\
\text { FEPA } \\
\text { standard }\end{array}$ & $<40$ & $6.5-8.5$ & 0.013 & $<1000$ & 30 & 30 & NSF & NSF & NSF & NSF & 40 & NSF \\
\hline
\end{tabular}

oscillations. (Verma and Agarwal, 2006) Studies have shown that the superficial layer of fresh water is constantly stirred by rinds which accelerates the current and enhances its thermal conductivity (Verma and Agarwal, 2006). High values of the conductivity could be attributed to the fact that $S$. officinarum rinds-contaminated sample had more TSS otherwise called perfect insulators that prevented the movement of current heat energy through the water medium as against the other samples.

The turbidity of Nworie river at the dumping was $0.16 \mathrm{mg} / \mathrm{l}$ compared to $1.86 \mathrm{mg} / \mathrm{l}$ at the upstream site. The relatively high turbidity at the dumping site could be due to high TSS

\section{Nutrient concentrations}

Nitrates, sulphates, and phosphates are products formed by the replacement of some or all of the hydrogen of a nitric, sulphuric and phosphoric acids respectively by metals (Verma and Agarwal, 2006). The water sample from dumping site had the highest value of phosphate, nitrate and sulphate compared to the other samples. Phosphates and nitrates are more important to metabolism in plants as they serve as nutrient for aquatic plants. When the plants, eventually die, the plant debris undergo aerobic biodegradation leading to anoxic conditions in the water body. This would lead to detrimental effects on organisms that require dissolved oxygen for their survival.

\section{Microbiological water quality}

The microorganisms isolated from the three water samples included the following bacterial species: Staphylococcus sp., Escherichia sp., Streptococcus sp., Kebsiella sp., and Baccillus sp. The high bacterial load of $4.7 \times 10^{5} \mathrm{cfu} / \mathrm{ml}$ (Table 2) in water sample from the dumping site could be explained by the high organic matter decomposition from sugar cane rinds wastes discharged into the river. Human wastes emanating from inhabitants living in the vicinity of the dumping site could have contributed to the high bacterial loads compared to the upstream site, which had $2.8 \times 10^{5} \mathrm{cfu} / \mathrm{ml}$. The isolation of these microbial pathogens (Table 4) and the values of some physicochemical parameters that are above the WHO/FEPA accepted standards is an indication of serious contamination of Nworie river by dumped sugar cane wastes. This level of contamination is a serious threat to the quality of the river since water from it at that point cannot be used by humans and animals. 
Table 2: Total heterotrophic bacterial counts.

\begin{tabular}{lc}
\hline Sample & Total heterotrophic bacterial counts $(\mathbf{c f u} / \mathbf{m l})$ \\
\hline $\mathrm{A}$ & $4.7 \times 10^{5}$ \\
$\mathrm{~B}$ & $2.8 \times 10^{5}$ \\
$\mathrm{C}$ & $0.8 \times 10^{2}$ \\
\hline &
\end{tabular}

Table 3: Microbial isolates and their different sample sites.

\begin{tabular}{|c|c|c|c|c|c|}
\hline \multirow[t]{2}{*}{ Sample } & \multirow[b]{2}{*}{ Staphylococcus.sp. } & \multicolumn{2}{|c|}{ Micro organisms isolated } & \multirow[b]{2}{*}{ Klebsciella.sp. } & \multirow[b]{2}{*}{ Bacillr sp. } \\
\hline & & Escherichia.coli & Strepto coccus.sp & & \\
\hline $\mathrm{A}$ & + & + & + & + & - \\
\hline B & + & + & + & - & - \\
\hline $\mathrm{C}$ & + & + & - & - & - \\
\hline
\end{tabular}

Table 4: Percentage frequency distribution of bacterial isolates in the samples.

\begin{tabular}{llcc}
\hline Samples & \multicolumn{1}{c}{ Organisms } & Frequency & \% Distribution \\
\hline \multirow{4}{*}{$\mathrm{A}_{1}-\mathrm{A}_{3}$} & Gram positive cocci (Streptococcus sp.) & 1 & 25.0 \\
& Gram positive cocci (Staphylococcus sp.) & 1 & 25.0 \\
& Gram negative rod (Klebsiella sp.) & 1 & 25.0 \\
& Gram negative rod (Escherichia coli) & 1 & 25.0 \\
\hline \multirow{2}{*}{$\mathrm{B}_{1}-\mathrm{B}_{3}$} & Gram negative rod (Escherichia coli) & 2 & 50.0 \\
& Gram positive cocci (Staphylococcus sp.) & 1 & 25.0 \\
& Gram positive cocci (Streptococcus sp.) & 1 & 25.0 \\
\hline \multirow{2}{*}{$\mathrm{C}_{1}-\mathrm{C}_{3}$} & Gram positive cocci (Staphylococcus $s p$.) & 1 & 50.0 \\
& Gram negative rod (Escherichia coli) & 1 & 50.0 \\
\hline
\end{tabular}

\section{Conclusion and recommendations}

The results from the study revealed that there is pollution of the river as a result of $S$. officinarum wastes dumped in the river. This level of contamination observed from the results is a serious threat to the quality of the river, since water from it at that point cannot be used for human and animal activities. It is strongly recommended that waste disposal into streams and river in Nigeria should be closely monitored by FEBA and other relevant agencies on time, before the situation gets out of hand.

\section{REFERENCES}

Chapman D. 1992. Water Quality Assessment: a Guide to the Use of Biota, Sediments and Water in Environmental Monitoring. Chapman and Hall: London; 585-587.

Cheesbrough M. 1991. Medical Laboratory, Manual for Tropical Countries (Vol. 2). Cambridge press: Cambridge; 9-70.
Gordon AM. 1990. Drinking Water Microbiology. Spinger-verlag: New York; 429-437.

Greenberg A. 1992. Standard Methods for the Examination of Water and Waste Water $\left(18^{\text {th }}\right.$ edn). APHA-AWWA-WEF: Washington DC.

Holdgate MW. 1979. Inorganic Pollutants. A Perspective of Environmental Pollution. Cambridge University Press; 155-165.

Holt JG, Krieg WR, Sneath PHA, Staley JT, Williams. 1994. Bergey's Manual of Determinative Bacteriology $\left(9^{\text {th }}\right.$ edn $)$. Williams and Wilkins Baltimore.

IPAN (Institute of Public Analysis of Nigeria). 2005. Pre-admission Training Workshop on Foods, Drugs, Cosmetics and Water. Environmental and Petroleum Proceedings.

James S. 1995. The Analytical Chemistry of Food $\left(1^{\text {st }}\right.$ edn). New York chapman and Hall; 82-90. 
Lynch JM, Poole NJ. 1979. Microbial Ecology: A conceptual Approach. Mc Graw Hill publishing company: New York.

Okafor N. 1985. Water Pollution and Treatment. Fourth dimension Publishing Company Ltd.: Enugu, Nigeria; 35-40.

Ray NK, Chan FC, Pelozer MJ. 1992. Microbiology Concept and Application (International edn). Mc Graw Hill Inc.; 40-47.

Ubong IU, Gobo AE. 2001. Fundamentals of Environment Chemistry and Meterology. Tom and Hawry Publication Ltd.: Port Harcourt, Nigeria; 264-270.
Verma PS, Agarwal VK. 2006. Environmental Biology (12 ${ }^{\text {th }}$ edn). S. Chand and company Ltd.: New Delhi, India; 154310.

Walter L. 1981. Handbook of Water Purification. Mc Graw Hill Book company: England.

World Health Organization (WHO). 2003. MCPA in Drinking Water. Background document for preparation of WHO Guidelines for drinking water. General World Health Organization, WHO/SDE/WSH/03, 04/38). 